\title{
Morphometric Analysis of Offin River Basin using Remote Sensing and GIS Technology in Ghana
}

\author{
Bismark Mensah-Brako ${ }^{1}$, Wilson Agyei Agyare ${ }^{1}$, Ebenezer Mensah ${ }^{1}$ and Richard Kotei ${ }^{2}$ \\ ${ }^{1}$ Department of Agricultural and Biosystems Engineering, College of Engineering, Kwame Nkrumah University of \\ Science and Technology, Kumasi, Ghana \\ ${ }^{2}$ Department of Agriculture Engineering and Mechanization, College of Agriculture Education, University of Education, Winneba, Mampong- \\ Ashanti, Ghana
}

\begin{abstract}
The paper examined morphometric characteristics of Offin River Basin in Ghana using Remote Sensing (RS) and Geographic Information System (GIS) techniques. Advanced Spaceborne Thermal Emission and Reflection Radiometer (ASTER) data with $30 \mathrm{~m}$ spatial resolution was used for the study. Different morphometric parameters including stream order, stream length, bifurcation ratio, relief ratio, drainage density, stream frequency, drainage texture, form factor, circularity ratio, elongation ratio, infiltration number and ruggedness number and their impact on hydrological processes such as infiltration, runoff, peak flow, overland flow and erosion in the Offin River Basin were discussed. The result revealed that Offin River Basin exhibited a dendritic drainage pattern with higher values of drainage density $\left(13.02 \mathrm{~km} / \mathrm{km}^{2}\right)$, drainage texture (9.60), infiltration number (8.07) and ruggedness number (7.26). These values make the basin prone to structural control, high surface runoff and more susceptible to soil erosion and recurrent flooding. Morphometric study of the five major watersheds in the basin also indicated that the watersheds are prone to soil erosion and high runoff generation associated with flatter peak flow creating conductive environment for watershed conservation measures. The results obtained in the Offin River Basin and it watersheds could serve as a valuable empirical data for building a robust physical soil and water resources conservation structures and management plan for sustainable basin and watershed management.
\end{abstract}

Index Terms: Offin river basin, Morphometric characteristics, Remote Sensing, GIS

\section{INTRODUCTION}

Morphometry is the measurement and mathematical evaluation of earth surface configuration, dimension, shape and landform processes (Obi Reddy et al. 2002). A quantitative assessment of morphometric characteristics of a drainage basin has been found very useful in the determination of hydrological processes including runoff generation, peak flow, infiltration rate and length of overland flow for soil and water conservation and natural resources planning and management (Yasmin et al., 2013). Javed et al. (2011), Lama et al., (2015) and Eahya (2017) in India and Diakakis (2011) in Greece opined that morphometric parameters have been used to assess groundwater potentials, mapping of flood and erosion prone areas and watershed management.

Ali et al. (2017) indicated that morphometric analysis of drainage system is helpful in an appraisal of water resource potential, watershed management and flood risk management. Gardiner (1990) indicated that morphometric characteristics of drainage basin have been used to predict flooding and estimation of erosion rates and runoff generation. The quantitative study of river basin also provides accurate data related to geology, geomorphology, groundwater potential and basin management.

Therefore, morphometric assessment is an essential in examining hydrology of river basin for sustainable use of land and water resources and for effective management of water induced disasters.

However, a comprehensive study of morphometric characteristics of a drainage river basin involves the measurement of drainage network, basin geometry, drainage texture and relief features through basin area, perimeter, stream orders, length of drainage channels, drainage density, stream frequency, bifurcation ratio, elongation ratio, circularity ratio, infiltration number, form factor, basin relief, relief ratio, slope, ruggedness number and others.

In addition, the use of remote sensing and GIS in morphometric study has been increased and provides an essential tool in the assessment of morphometric characteristics. Gebre et al. (2015) indicated that remote sensing and GIS technology provide effective tool for extraction of river basin and its drainage network. Biswajit (2016) noted that remote sensing and GIS help to explain terrain parameters such as nature of bedrock, infiltration, surface runoff and soil erosion. This study examined the morphometric characteristics of the Offin River Basin using remote sensing and GIS. The outcome of the study could be useful for managers and planners in the basin while implementing soil and water conservation measures.

\section{MATERIALS AND METHODS}

Study area characteristics

Offin river basin forms part of the southwestern river basin systems of Ghana. The basin lies within Latitude $5^{\circ} 30^{\prime}$ to $6^{\circ} 54^{\prime}$ North and Longitude $1^{\circ} 30^{\prime}$ to $2^{\circ} 15^{\prime}$ 'West. The study sprawls over a land area of $6,561 \mathrm{~km}^{2}$. Offin River and its main tributaries originated from the Eastern and the Northern fringes and flow Southwards through Ashanti uplands near Mampong in the Ashanti Region and discharge into Pra River in theCentral Region before entering Gulf of Guinea near Shama in the Western Region of Ghana. The Offin River Basin is underlain by Birimian, Tarkwaian and Dahomeyan formations covering $4496.42 \mathrm{~km}^{2}$ (68.53\%), 
$1346 \mathrm{~km}^{2}(20.55 \%)$ and $718.58 \mathrm{~km}^{2}(10.95 \%)$ respectively (Figure 1). The highest elevation of the basin is $550 \mathrm{~m}$ and lowest is $100 \mathrm{~m}$ above sea level. Forest Ochrosols (Acrisols), Alisols, Fluvisols, Forest Lithosols (Leptosols)

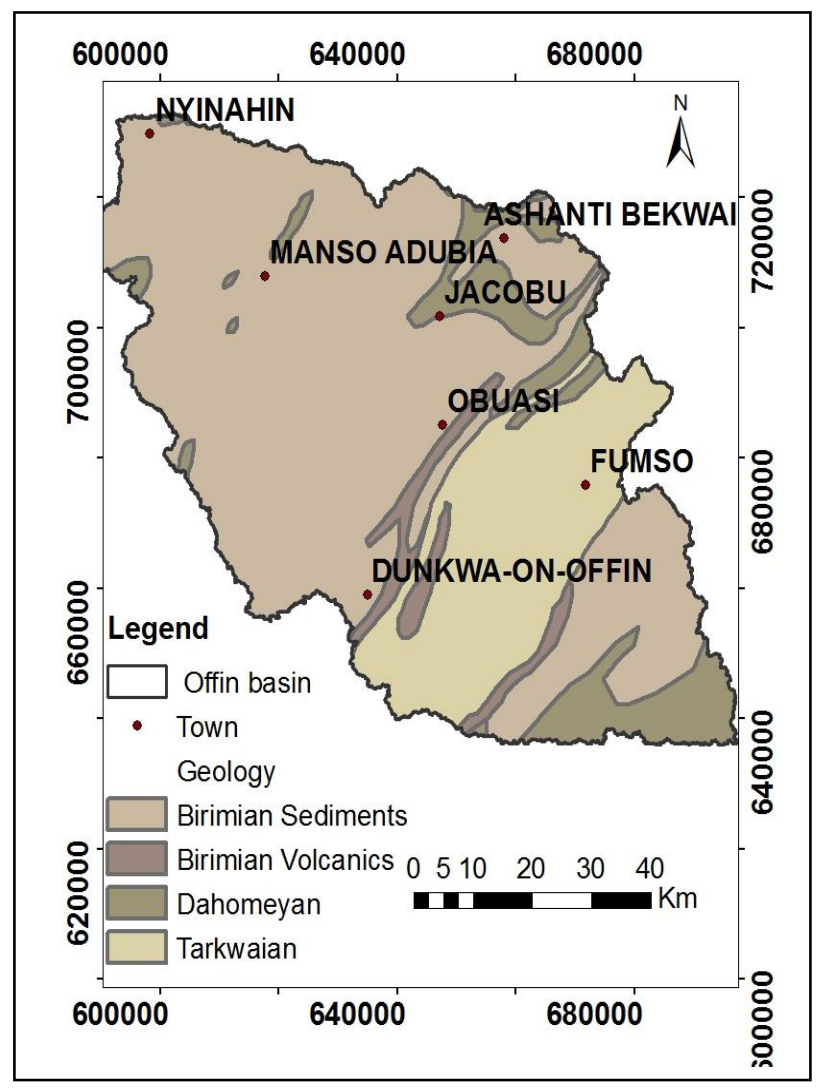

Figure 1: Geology of the Offin River Basin

Offin River Basin falls within moist semi-deciduous forest zone with annual rainfall between $1,250 \mathrm{~mm}$ and $1,700 \mathrm{~mm}$. The basin experiences a bi-modal rainfall pattern with major rainy season starts from March to July with the peak in June. The minor rainy season begins in September and ends in November. The mean annual minimum temperature is 22 ${ }^{\circ} \mathrm{C}$, while maximum temperature for the hottest months is $33.2{ }^{\circ} \mathrm{C}$. The annual average humidity varied between $48 \%$ and $88 \%$. It ranged from 83 to $87 \%$ in the morning and 48 $\%$ to $67 \%$ in the afternoon with an average sunshine of 5.0 hours per day. Wawa (Triplochiton scleroxylon), Mahogany (Khaya ivorensis) and Onyina (Ceiba pentandra) are the main tree species. In certain parts of the basin, the natural forest cover has been turned into degraded land through indiscriminate exploitation of timber, illegal gold mining and sand winning activities Farming activities are particularly smallholding and vastly rain-fed. Among the and Lixisols (Figure 2) are the main soil type found in the Offin river basin. Acrisols are wide-spread with geographical extent of 5, $290.6 \mathrm{~km}^{2}$.

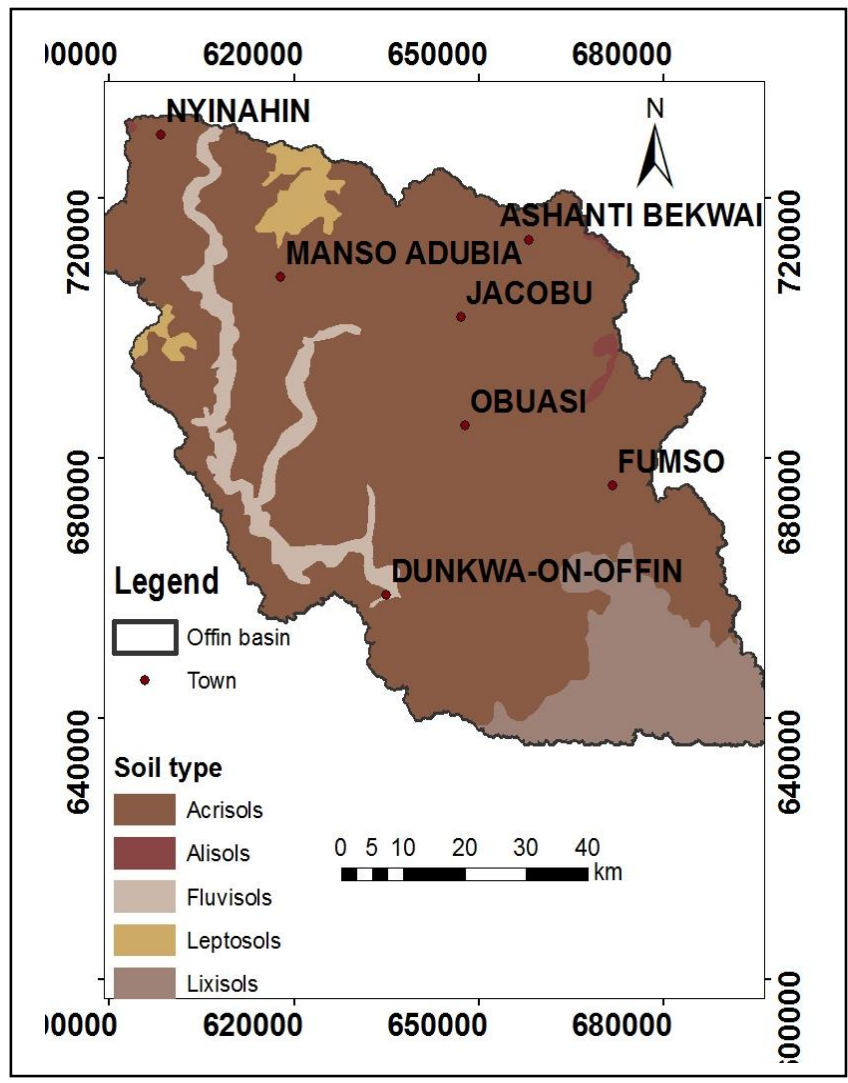

Figure 2: Soil type within the Offin River Basin

food crops plantain, cassava, cocoyam, and maize are grown extensively with less than 1.5 hectares per farmer in the basin.

Methodology

The advanced Spaceborne Thermal Emission and Reflection Radiometer (ASTER) data with $30 \mathrm{~m}$ spatial resolution (Figure 3) were used and processed with ArcGIS 10.1 software to obtain Digital Elevation Model (DEM) for Offin River Basin (Figure 4). The DEM data was projected to the Universal Transverse Mercator (UTM) projection system zone $34 \mathrm{~N}$ and datum of World Geodetic System 84 (WGS84). The resulting DEM and pour point (user-supplied point to cells of highest flow accumulation) were the two input parameters used for the extraction of drainage systems based on the Strahler's system of classification. 


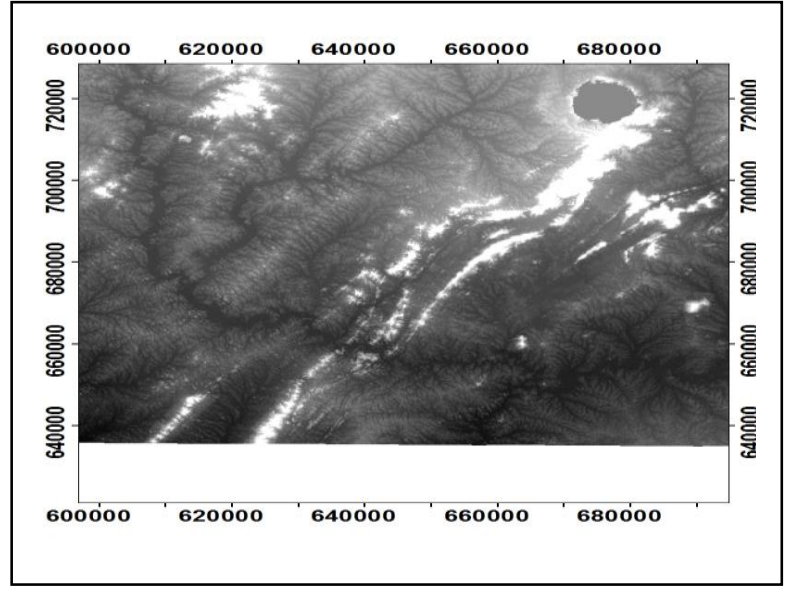

Figure 3: ASTER DEM covering the Offin river basin

Terrain pre-processing was done to fill all the sinks. Terrain characteristics such as flow direction, flow accumulation, stream number and stream order were retrieved using ArcGIS 10.1. Different morphometric parameters such as stream length, stream length ratio, bifurcation ratio, basin

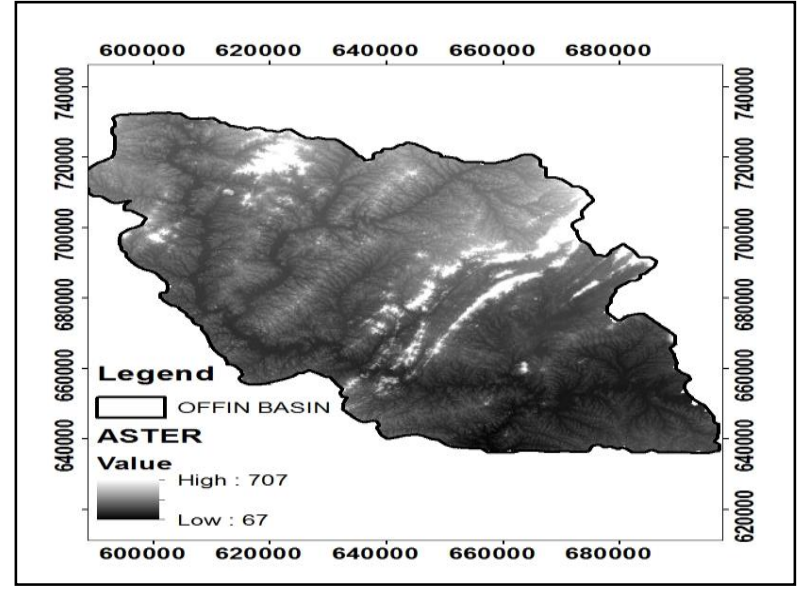

Figure 4: ASTER DEM of the Offin River Basin

length, relief ratio, elongation ratio, drainage density, stream frequency, form factor and circularity ratio were determined using the formulas in the Table 1. In addition, the slopes were retrieved from the ASTER DEM using the slope tool in ArcGIS 10.1 version.

Table 1: Morphometric parameters and methods used in the Offin River Basin

\begin{tabular}{|c|c|c|c|}
\hline \multicolumn{2}{|c|}{ Morphometric parameter } & Formula & References \\
\hline \multirow{4}{*}{$\begin{array}{l}\text { Drainage } \\
\text { Network }\end{array}$} & Stream order $(\mathrm{Nu})$ & Hierarchical rank & Strahler (1964) \\
\hline & Stream number & $\mathrm{N} u=\mathrm{N}_{1}+\mathrm{N}_{2}+\ldots \ldots .+\mathrm{N}$ & Horton (1945) \\
\hline & Mean stream length & $\mathrm{L}_{\mathrm{m}}=\mathrm{Lu} / \mathrm{Nu}$ & Horton (1945) \\
\hline & Bifurcation ratio $\left(\mathrm{R}_{\mathrm{b}}\right)$ & $\mathrm{R}_{\mathrm{b}}=\mathrm{Nu} / \mathrm{Nu}+1$ & Schumm (1956) \\
\hline \multirow{3}{*}{$\begin{array}{l}\text { Basin } \\
\text { Geometry }\end{array}$} & Form factor $\left(\mathrm{F}_{\mathrm{f}}\right)$ & $\mathrm{F}_{\mathrm{f}}=\mathrm{A} / \mathrm{Lb}^{2}$ & Horton (1945) \\
\hline & Circularity ratio $\left(\mathrm{R}_{\mathrm{c}}\right)$ & $\mathrm{R}_{\mathrm{c}}=4 \pi \mathrm{A} / \mathrm{P}^{2}$ & Miller (1953) \\
\hline & Elongation ratio $\left(\mathrm{R}_{\mathrm{e}}\right)$ & $\mathrm{R}_{\mathrm{e}}=2 \mathrm{H}(\mathrm{A} / \mathrm{p}) / \mathrm{Lb}$ & Schumm (1956) \\
\hline \multirow{5}{*}{ Texture } & Stream frequency $\left(\mathrm{F}_{\mathrm{s}}\right)$ & $\mathrm{F}_{\mathrm{s}}=\mathrm{Nu} / \mathrm{A}$ & Horton (1945) \\
\hline & Drainage density $\left(\mathrm{D}_{\mathrm{d}}\right)$ & $\mathrm{D}_{\mathrm{d}}=\mathrm{Lu} / \mathrm{A}$ & Horton (1945) \\
\hline & Infiltration number $\left(\mathrm{I}_{\mathrm{f}}\right)$ & $\mathrm{I}_{\mathrm{f}}=\mathrm{Dd} \times \mathrm{Fs}$ & Faniran (1968) \\
\hline & Drainage texture $\left(D_{t}\right)$ & $\mathrm{D}_{\mathrm{t}}=\mathrm{Nu} / \mathrm{P}$ & Smith (1950) \\
\hline & Length of overland flow $\left(\mathrm{L}_{\mathrm{g}}\right) \mathrm{km}$ & $\mathrm{L}_{\mathrm{g}}=1 / \mathrm{Dd} \times 2$ & Horton (1945) \\
\hline \multirow{3}{*}{$\begin{array}{l}\text { Relief } \\
\text { aspects }\end{array}$} & Basin relief (R) & $\mathrm{R}=\mathrm{H}-\mathrm{h}$, & Schumm (1956) \\
\hline & Relief ratio (Rr) & $\mathrm{Rr}=\mathrm{R} / \mathrm{Lb}$ & Schumm (1956) \\
\hline & Ruggedness number (Rn) & $\mathrm{Rn}=\mathrm{R} \times \mathrm{Dd}$ & Strahler (1957) \\
\hline
\end{tabular}

$A$ is area, $P$ is the parameter, $L b$ is the basin length, Nu is number of streams of any given order and $N(u+1)$ is number in the next higher order,

$H$ is maximum elevation and $h$ is minimum elevation within the basin

\section{RESULTS AND DISCUSSION}

The morphometric characteristics of the Offin Basin were analyzed under drainage network, drainage geometry, drainage texture and relief features.

\section{Drainage network of the Offin River Basin}

The results revealed that the basin and it watersheds exhibited dendritic drainage pattern, indicating the presence of impervious bedrock formation. The stream order varied from first to seventh (Figures 6) with 3,102 streams in the first order, 605 streams in the second order, 202 streams in the third order, 39 streams in the fourth order, 7 streams in the fifth order, 1 stream in the sixth order and 1 stream in the seventh order (Table 2). 


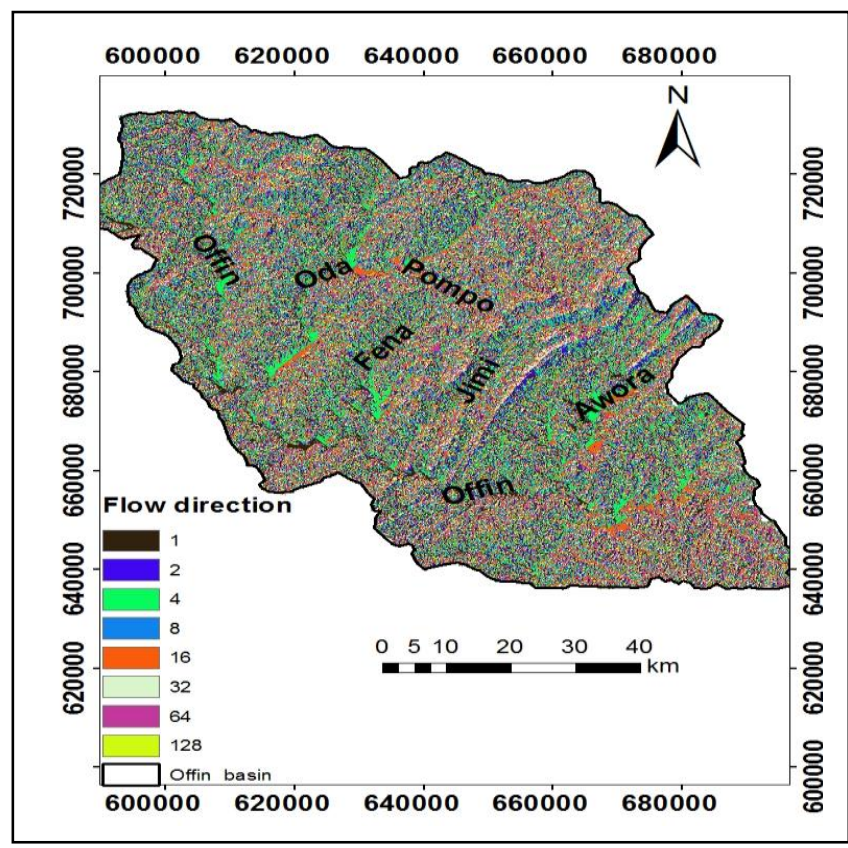

Figure 5: Flow direction in the Offin River Basin

The relationship between stream orders and stream numbers revealed rapid decrease from lower order streams to higher order streams (Table 2) and negative association between stream orders and stream numbers (Figure 7). The result implies that streams decreases in geometric progression as the stream order increases. Similar relationship has been observed by Ali et al. (2017) in India.

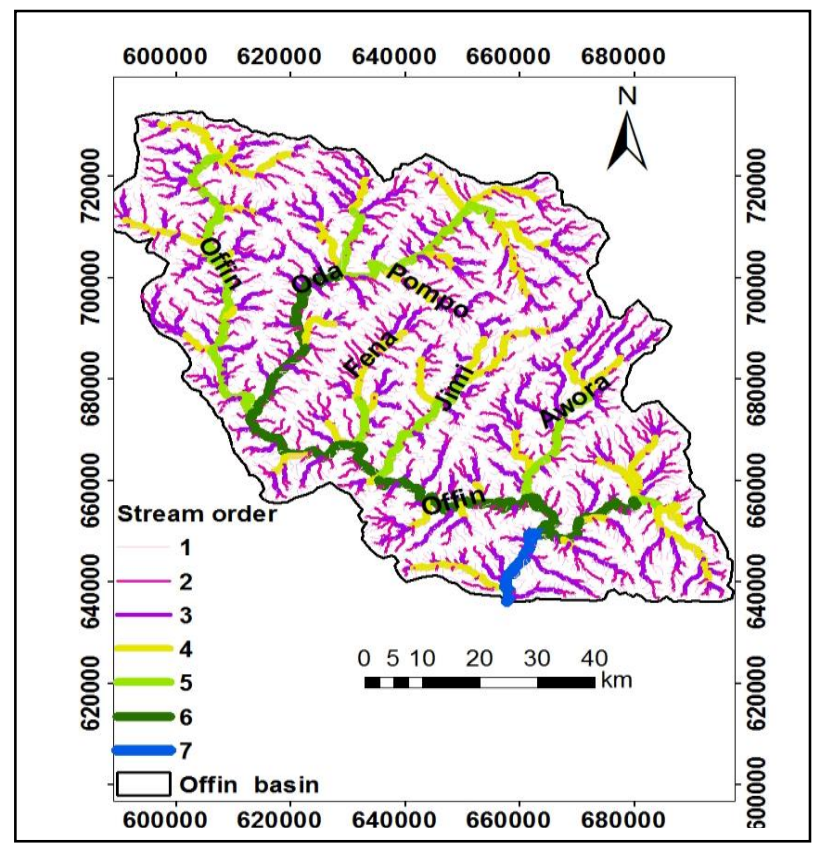

Figure 6: Stream order in Offin River Basin

The maximum stream order was found in the first order streams and second order streams, an indication of ephemeral streams, more prone to erosion and sudden floods (Chitra et al., 2011). The variation in stream order and stream number observed in the basin is mainly due to influence of topography and bedrock. These imply that Offin river basin has being developed over hard rock, high relief and steep slope.

Table 2: Number of streams in the Offin River Basin

\begin{tabular}{|c|c|c|c|c|c|c|c|c|}
\hline \multirow[b]{2}{*}{ Offin basin / watershed } & \multicolumn{5}{|c|}{ Number of streams $(\mathrm{Nu})$} & \multirow[b]{2}{*}{ VI } & \multirow[b]{2}{*}{ VII } & \multirow[b]{2}{*}{ Total } \\
\hline & $\mathrm{I}$ & II & III & IV & $\mathrm{V}$ & & & \\
\hline Offin river basin & 3102 & 605 & 202 & 39 & 7 & 1 & 1 & 3957 \\
\hline Awora watershed & 367 & 78 & 18 & 3 & 1 & - & - & 467 \\
\hline Assin watershed & 370 & 95 & 27 & 6 & 2 & 1 & - & 501 \\
\hline Oda watershed & 730 & 223 & 50 & 10 & 2 & 1 & & 1016 \\
\hline Amansie watershed & 431 & 172 & 41 & 8 & 1 & - & - & 653 \\
\hline Fena watershed & 240 & 57 & 12 & 3 & 1 & - & - & 313 \\
\hline
\end{tabular}




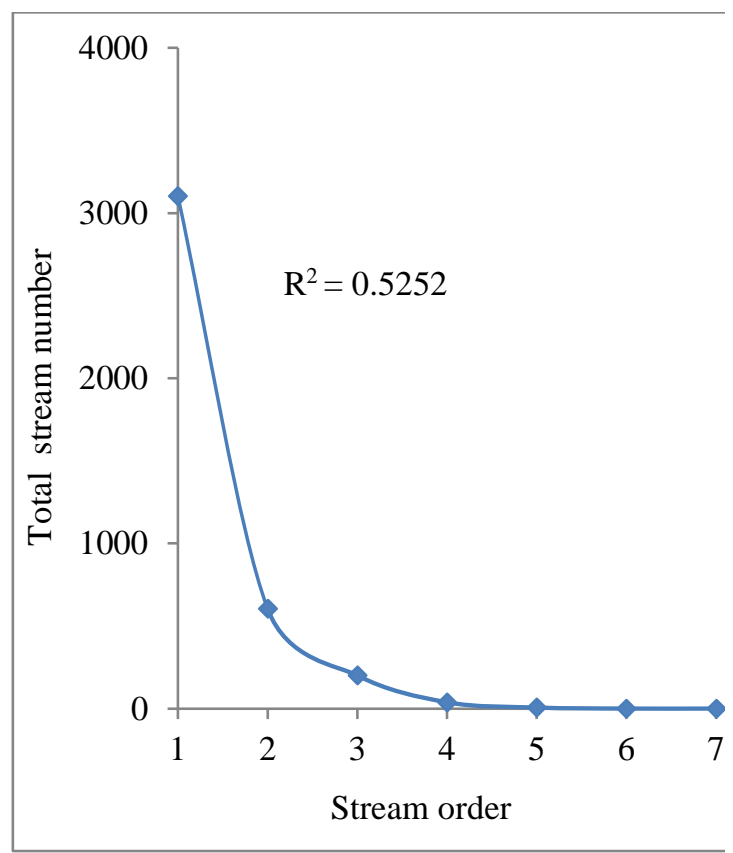

Figure 7: Stream order and number of streams

Stream length has an important relationship with discharge and surface runoff. Large number of streams of smaller lengths is indicative of higher slopes and impermeable bedrocks while small number of relatively longer lengths of streams is indicative of much flatter gradients and permeable bedrock formation (Sethupathi et al., 2011). In Offin River Basin, total lengths of streams were found predominantly in first order streams and decreases with the increase in stream order. Oda, Amansie, Assin and Awora watersheds had more number of streams of smaller lengths

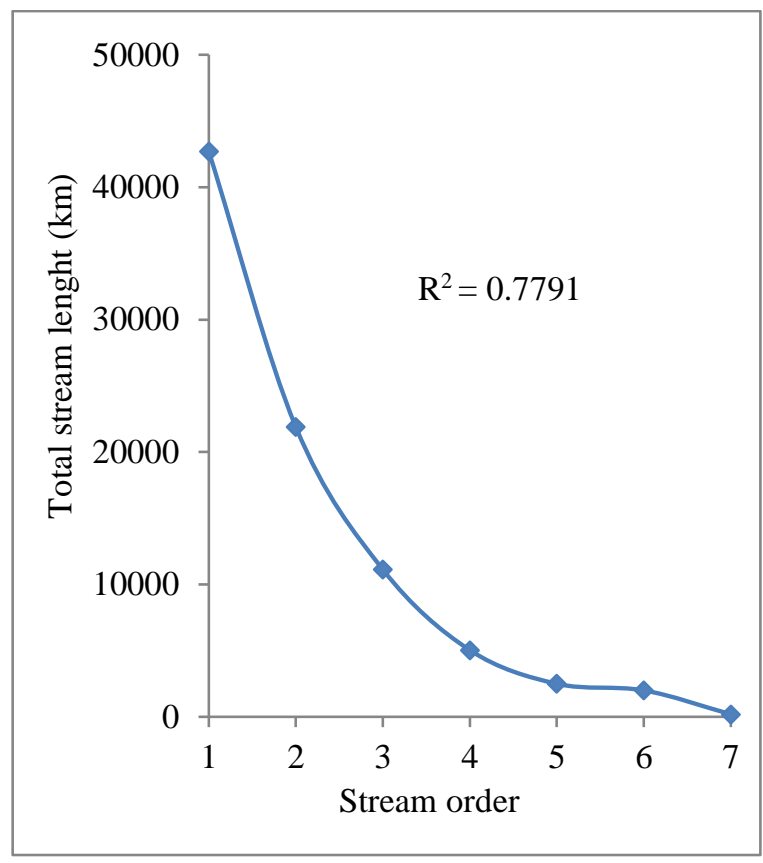

Figure 8: Stream order and stream length

in the first order (Table 3) and also plot of stream length of a given order and stream order (Figure 8) showed a negative pattern and concave in nature, an indication of less permeability and erosion characteristics. Similar relationship has also been observed by Eahya (2017) in India. In India (Thomas et al., 2011) and in China (Hlaing et al., 2008) opined that more streams of smaller length are developed in a basin where bedrock formation and sub-soil materials are less permeable.

Table 3: Stream length in the Offin River Basin

\begin{tabular}{|c|c|c|c|c|c|c|c|c|}
\hline \multirow{2}{*}{ Offin basin / watershed } & \multicolumn{4}{|c|}{ Stream length $(\mathrm{Lu})(\mathrm{km})$} & \multirow[b]{2}{*}{$\mathrm{V}$} & \multirow[b]{2}{*}{ VI } & \multirow[b]{2}{*}{ VII } & \multirow[b]{2}{*}{ Total } \\
\hline & $\mathrm{I}$ & II & III & IV & & & & \\
\hline Offin river basin & 42688 & 21891 & 11126 & 5036 & 2494 & 1997 & 193 & 85425 \\
\hline Awora watershed & 4057 & 2122 & 1687 & 389 & 364 & - & - & 8619 \\
\hline Assin watershed & 5551 & 2777 & 1425 & 827 & 56 & 316 & - & 10952 \\
\hline Oda watershed & 11022 & 6313 & 2753 & 1368 & 684 & 570 & - & 22710 \\
\hline Amansie watershed & 8958 & 4184 & 1995 & 986 & 869 & - & - & 16992 \\
\hline Fena watershed & 2264 & 1453 & 421 & 289 & 118 & - & - & 4545 \\
\hline
\end{tabular}

Drainage geometry of the Offin river basin

The geometry parameters like area, perimeter, length, bifurcation ratio and mean bifurcation ratio results have been presented in Table 4. Nishant et al. (2013) indicated that basin area, basin perimeter and basin length are essential morphometric parameters which influences the shape, size and volume of water retaining in the basin. These parameters also impact on hydrological characteristics as they directly affect the size of storm hydrograph and magnitude of peak flow, time to peak flow and runoff generation. 
Table 4: Drainage geometry of the Offin River Basin

\begin{tabular}{|c|c|c|c|c|c|c|c|c|c|c|}
\hline \multirow{2}{*}{$\begin{array}{l}\text { Basin / } \\
\text { watershed }\end{array}$} & \multirow{2}{*}{$\begin{array}{r}\text { Area } \\
\left(\mathrm{km}^{2}\right)\end{array}$} & \multirow{2}{*}{$\begin{array}{l}\text { Perimeter } \\
\quad(\mathrm{km})\end{array}$} & \multirow{2}{*}{$\begin{array}{c}\text { Length } \\
(\mathrm{km})\end{array}$} & \multicolumn{6}{|c|}{ Bifurcation ratio } & \multirow[b]{2}{*}{ Mean } \\
\hline & & & & $\begin{array}{l}\text { I/ } \\
\text { II }\end{array}$ & $\begin{array}{l}\text { II/ } \\
\text { III }\end{array}$ & $\begin{array}{l}\text { III/ } \\
\text { IV }\end{array}$ & $\begin{array}{l}\text { IV/ } \\
\text { V }\end{array}$ & $\begin{array}{l}\text { V/ } \\
\text { VI }\end{array}$ & $\begin{array}{l}\text { VI/ } \\
\text { VII }\end{array}$ & \\
\hline Offin basin & 6561 & 412 & 142 & 5.1 & 3.0 & 5.2 & 5.6 & 7.1 & 1 & 5.20 \\
\hline Awora watershed & 670 & 187 & 44 & 4.7 & 4.3 & 6.0 & 3.0 & - & - & 4.50 \\
\hline Assin watershed & 855 & 296 & 41 & 3.9 & 3.5 & 4.5 & 3.0 & 2 & - & 3.38 \\
\hline Oda watershed & 1746 & 299 & 64 & 4.2 & 4.5 & 5.0 & 5.0 & 2 & - & 4.00 \\
\hline Amansie watershed & 1260 & 242 & 74 & 3.3 & 4.2 & 5.1 & 8.0 & - & - & 5.00 \\
\hline Fena watershed & 365 & 12 & 34 & 3.2 & 3.6 & 3.7 & 3.0 & - & - & 3.70 \\
\hline
\end{tabular}

According to Horton (1945), bifurcation ratio varies from a minimum of 2 in "flat drainage basins" and 3 to 4 in "highly dissected drainage basins". The bifurcation ratio ranged between 3.0 and 5.0 which indicate structural control on drainage pattern. The mean bifurcation ratio of Offin River Basin was found to be 5.20, while watersheds bifurcation ratio ranged between 3.38 and 5.10 (Table 4), an indication of structurally controlled on drainage development. Bifurcation ratio of Amansie, Awora, Fena and Oda watersheds (Table 4) indicated low permeability and more susceptible to erosion (Soni, 2016). Awora and Oda watersheds had high bifurcation ratio for first and second order streams which highlighted high runoff and flood potential. Similar findings have been reported by Kumar et al. (2012) and Lama et al. (2015) in India.

\section{Drainage texture of the Offin River Basin}

Morphometric parameters such as drainage density, drainage texture, stream frequency, elongation ratio, form factor and circularity ratio are considered as erosion characteristics (Gayen et al., 2013). Drainage texture values estimated in the Offin River Basin are presented in Table 5. Drainage density is a measure of how streams occur on the land surface. It reflects a balance between erosive forces of overland flow and the resistance of surface soils and rocks. The basin had high drainage density of $13.02 \mathrm{~km} / \mathrm{km}^{2}$ and the watersheds also ranged between 12.45 and 13.49 $\mathrm{km} / \mathrm{km}^{2}$ (Table 5) far above $5 \mathrm{~km} / \mathrm{km}^{2}$ (Smith (1950). These suggest that the basin is impermeable, poorly drained and high surface runoff potential with negative impacts on soil bulk density, soil infiltration and plant root development. A study of Gardiner (1995) in India suggested that high drainage density is associated with impermeable rock formation.

Table 5: Drainage texture in the Offin River Basin

\begin{tabular}{|c|c|c|c|c|c|c|}
\hline \multirow[t]{2}{*}{ Morphometric parameters } & \multirow{2}{*}{$\begin{array}{l}\text { Offin } \\
\text { basin }\end{array}$} & \multicolumn{4}{|c|}{ Watersheds } & \multirow[b]{2}{*}{ Fena } \\
\hline & & Oda & Assin & Awora & Amansie & \\
\hline Drainage density $\left(D_{d}\right)$ & 13.02 & 13.01 & 12.81 & 12.86 & 13.49 & 12.45 \\
\hline Drainage texture $\left(D_{t}\right)$ & 9.60 & 2.45 & 1.69 & 2.40 & 2.70 & 2.52 \\
\hline Infiltration number $\left(\mathrm{I}_{\mathrm{f}}\right)$ & 8.07 & 7.55 & 7.56 & 9.00 & 7.01 & 10.70 \\
\hline Stream frequency $\left(\mathrm{F}_{\mathrm{s}}\right)$ & 0.62 & 0.58 & 0.58 & 0.7 & 0.52 & 0.65 \\
\hline Length of overland flow $\left(\mathrm{L}_{\mathrm{g}}\right)$ & 0.15 & 0.15 & 0.16 & 0.15 & 0.16 & 0.16 \\
\hline Form factor $\left(\mathrm{R}_{\mathrm{f}}\right)$ & 0.33 & 0.43 & 0.50 & 0.33 & 0.36 & 0.37 \\
\hline Circularity ratio $\left(\mathrm{R}_{\mathrm{c}}\right)$ & 0.49 & 0.33 & 0.12 & 0.24 & 0.30 & 0.32 \\
\hline Elongation ratio $\left(\mathrm{R}_{\mathrm{e}}\right)$ & 0.65 & 0.74 & 0.80 & 0.65 & 0.68 & 0.64 \\
\hline
\end{tabular}

Form factor is an indicator of flood formation, degree of erosion and transport capacities of sediment load in a basin (Soni, 2016). The value of form factor ranged from 0.100.80 . Lesser the value of form factor, the more elongated will be the drainage basin. The basins with high form factors 0.8 , have high peak flows of shorter duration, whereas, elongated drainage basin with low form factors have a lower peak flow of longer duration. Form factor of 0.33 and 0.34 were obtained for the basin and watersheds respectively (Table 5). The low values of form factor obtained suggested elongated basin with flatter peak flows of longer duration which leads to ground water percolation.

Horton (1945) found that infiltration capacity is an important factor which effects drainage texture. He further indicated that drainage texture has strong correlation with drainage density and stream frequency. Low drainage density leads to coarse drainage texture while high drainage density leads to fine drainage texture, which in turn depends on infiltration rates of bed rock formation. Smith (1950) classified drainage texture as: $<2$ very coarse, $2-4$ coarse, $4-$ 6 moderate, 6-8 fine and $>8$ very fine. Drainage texture obtained for the basin was 9.60 depicting fine drainage texture (Table 5). Low value of drainage texture was recorded in watersheds, indication of coarse drainage texture. The fine to coarse drainage texture observed in the basin could be attributed to rock formation. The fine drainage texture coupled with high values of drainage density and infiltration number suggest that the basin has less permeable, low infiltration, high runoff and recurrent flooding (Gebre et al., 2015).

Length of overland flow $\left(\mathrm{L}_{\mathrm{g}}\right)$ is the length of water over the ground before it gets concentrated in to definite stream channels. Length of overland flow $\left(\mathrm{Lg}_{\mathrm{g}}\right)$ is an important morphometric variables influencing both hydrologic and physiographic development of a drainage basin. It also affects surface runoff and directly governs by rain intensity, infiltration capacity, slope and surface roughness. The Offin River Basin had overland flow of $0.15 \mathrm{~km}$ and watersheds 
also have mean value of $15 \mathrm{~km}$. Offin river basin had circularity ratio value of 0.49 , whereas in watersheds the values ranged between $0.12-0.33$ (Table 5 ). The circularity ratio results reveal elongated basin, strong structural control and moderate to high runoff discharge (Javed et al., 2009).

The elongation ratio reflects the shape of the drainage basin which gives an idea about the hydrological characteristics of a drainage basin, i.e circular basin or watershed is more efficient in the discharge of surface runoff than an elongated basin or watershed whereas, time of concentration of soil runoff is less in elongated basin. The elongation ratio usually ranged from 0.6 to 1.0 . Values from 0.6 to 0.8 are associated with high relief and steep slopes. The Offin basin had elongation ratio of 0.65 and watersheds ranged from 0.64-0.80. Elongation ratio suggested that Offin basin that Fena, Amansie and Awora watersheds exhibited elongated shape with high relief, prone soil erosion and high sediment load discharge. India (Sharma et al., 2012) found that higher values of elongation ratio are indication of high susceptibility to erosion and runoff generation. Values of form factor, elongation ratio and circularity ratio indicated that the basin has elongated shape with flatter peak flow of longer duration. Flood flows of such basins can easily be

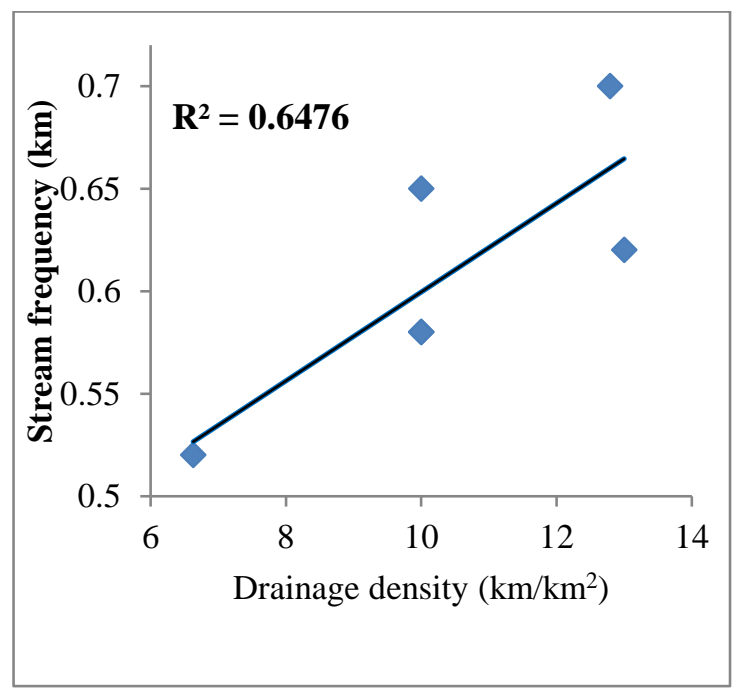

Figure 9: Drainage density and stream frequency

Slope is an essential attribute of land surface that has direct controls on runoff. Higher slope results in rapid runoff and increased erosion rate (potential soil loss) with less groundwater recharge potential. The slope in Offin River Basin varied from low (0-3), very gentle (3-5\%), gentle (5$10 \%)$, moderate $(10-15 \%)$, moderately steep (15-20\%), steep (20-25\%), very steep (25-35\%), most steep (35$45 \%$ ), and extremely steep (above $45 \%$ ) (Figure 10). The flat to gentle slope could be more useful for agricultural activities. managed than those of a circular basin (Wandre and Rank 2013).

The number of stream fragments per unit area is called stream frequency. It is characterized by surface runoff, steeper land surface, and impermeable subsurface material and high relief characteristics. Stream frequency primarily depends on the lithology of the basin and reflects the drainage texture of the drainage network. Stream frequency recorded $0.62 \mathrm{~km}$ and the watersheds ranged from 0.52-0.70 $\mathrm{km}$ exhibiting high impermeable geology, high relief and strong structural control on drainage development. Higher stream frequency leads to higher surface runoff and impermeable materials (Biswajit, 2016). The value of stream frequency for the basin exhibited positive correlation with drainage density (Figure 9) indicating the increase in stream population with respect to increase in drainage density.

Infiltration number is the product of drainage density and stream frequency. It is inversely proportional to the infiltration capacity of the basin. Higher the infiltration number, the lower will be the infiltration. The infiltration number was found to be 8.07 in the basin, suggesting low infiltration, high bulk density, higher drainage density and high runoff production. High value of infiltration number suggested that there is adequate scope for surface and ground water development (Singh 2006).

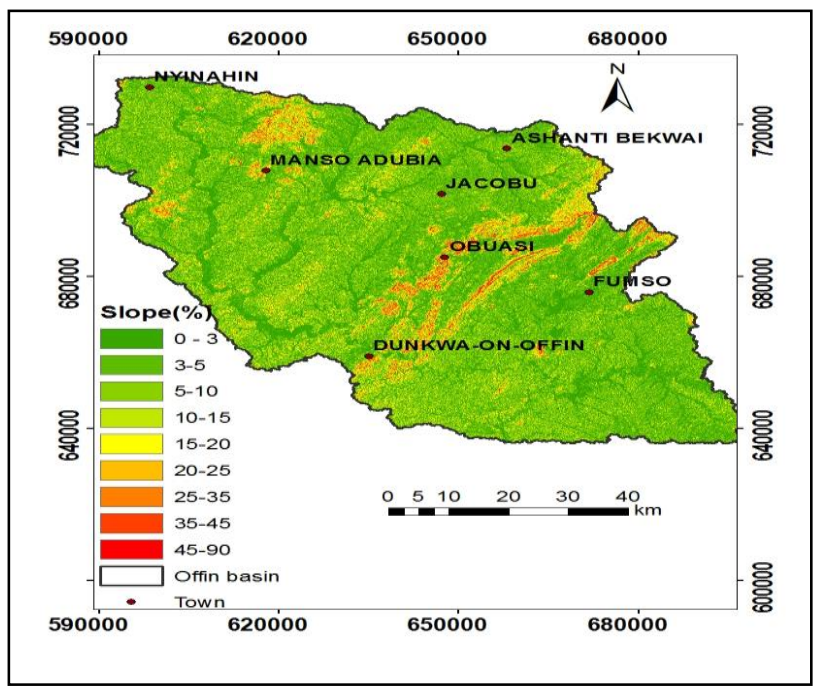

Figure 10: Slope of Offin River Basin

Relief characteristics of the Offin river basin

Basin relief is the elevation difference of the highest and lowest point of the valley floor within the basin. The basin relief was found to be $550 \mathrm{~m}$ with high values in Oda, Amansie, Fena and Awora watershed (Table 6). Relief ratio measures the overall steepness of a drainage basin and is an indicator of the intensity of erosion process on slopes. Oda, Awora and Assin watersheds had the highest values of relief ratio. The high value of relief ratio is a characteristics of hilly terrain associated with high runoff production and erosion potentials. Previous study in Ethiopia (Gebre et al., 2015) observed similar findings. 
Ruggedness number is the geometric characteristics of a drainage basin and it is used to measure surface unevenness and flash flood potential (Selvan et al., 2011). Ruggedness number of Offin river basin was 7.26 and all the watersheds ranged between 3.84 and 5.85, an indication of rugged topography, strong structural control, high drainage density and more susceptible to soil erosion and flash flood characteristics (Pareta and Pareta, 2011; Lama et al., 2015).

Table 6: Relief characteristics of the Offin River Basin

\begin{tabular}{|c|c|c|c|c|c|c|}
\hline \multirow[t]{2}{*}{ Morphometric parameters } & \multirow{2}{*}{$\begin{array}{l}\text { Offin } \\
\text { basin }\end{array}$} & \multicolumn{4}{|c|}{ Watersheds } & \multirow[b]{2}{*}{ Fena } \\
\hline & & Oda & Assin & Awora & Amansie & \\
\hline Basin relief (R) & 550 & 450 & 300 & 400 & 400 & 400 \\
\hline Relief ratio (Rr) & 0.004 & 0.008 & 0.007 & 0.010 & 0.005 & 0.004 \\
\hline Relative relief & 0.002 & 0.002 & 0.001 & 0.002 & 0.002 & 0.001 \\
\hline Ruggedness number & 7.26 & 5.85 & 3.84 & 5.14 & 5.40 & 4.98 \\
\hline
\end{tabular}

\section{CONCLUSION}

Different morphometric parameters in the Offin river basin and its impacts on hydrological characteristics such as surface runoff, peak flow, infiltration capacity, overland flow, etc were assessed using remote sensing and GIS. The study revealed that Offin River Basin is structurally controlled and characterized by high peak discharge, susceptibility to erosion and sudden flood resulting into loss of topsoil particularly at the down stream. Higher values of drainage density, drainage texture, and infiltration number and bifurcation ratio were recorded making Offin river basin less permeable, fine drainage texture, low infiltration capacity and more prone to soil erosion. The morphometry analysis of the five major watersheds in the basin also highlighted that the area is more prone to soil erosion and high sediment discharge resulting in streams and river sedimentations, loss of soil nutrients from farmlands and recurrent flooding. The result from the mophometric analysis in the basin and the various watersheds could be helpful in prioritizing the basin regarding soil and water conservation measures, flood control management and planning as well as assessing groundwater potentials for both agricultural and domestic needs.

\section{POLICY CONSIDERATION}

The following policy directions are suggested:

* Public and private sector partnership should be explored towards planning and implantation of soil and water resources conservation measures in Offin River Basin.

* Groundwater resources evaluation and its management plan for farming and domestic purposes in the Offin River Basin should be critically considered in the face of land use change and climate variability.

\section{ACKNOWLEDGEMENT}

We acknowledge the support of Directors and staff of Ministry of Food and Agriculture at Regional Office, Kumasi for assisting us in the field work.

\section{REFERENCES}

[1] Ali K., Bajracharya RM, Sitaula BK., Raut, N and Koirala, HL, 2017. Morphometric analysis of Gilgit River Basin in Mountainous Region of Gilgit-Baltistan Province, Northern Pakistan. Journal of Geosciences and Environment Protection, 5, 70-88. doi.org/10.4236/gep.2017.57008

[2] Biswajit M, 2016. Analysis of Hydrological Inferences through Morphometric Analysis: A Remote Sensing-GIS Based Study of
Gandheswari River Basin in Bankura District, West Bengal Int J. of Humanities \& Social Science Studies 2-4, 68-80

[3] Chitra C, Alaguraja P, Ganeshkumari K., Yuvaraj D and Manivel M, 2011. Watershed characteristics of Kundah sub-basin using remote sensing and GIS techniques. Int J Geomatics Geosci 2(1), 311-335

[4] Diakakis M, 2011. A method for flood hazard mapping based on basin morphometry: Application in two catchments in Greece, Natural Hazards, 56 (3), 2011, 803-814.

[5] Eahya Al Huda, 2017.. Morphometric Characteristics of Dikrong River Catchment in the Foot-Hills of Arunachal Himalayas . IOSR Journal of Humanities And Social Science (IOSR-JHSS) 22, (7), 13.

[6] Faniran A, 1968. The Index of Drainage Intensity-A Provisional New Drainage Factor. Aust J Sci 31: 328-330.

[7] Gardiner V, 1995. Channel networks: progress in the study of spatial and temporal variations of drainage density. In: Gornell A, Petts GE (eds) Change in river channels. Wiley, New York, pp 65-85

[8] Gardiner V, 1990. Drainage Basin Morphometry. In: Goudie, A., Ed., Geomorphological Techniques, Unwin Hyman, London, 71-81.

[9] Gayen S, Bhunia GS, Shi PK., 2013. Morphometric analysis of Kangshabati-Darkeswar Interfluves area in West Bengal, India using ASTER DEM and GIS techniques. Geol Geosci, 2(4), 1-10

[10] Gebre T, Kibru T, Tesfaye S and Taye G, 2015. Analysis of Watershed Attributes for Water Resources Management Using GIS: The Case of Chelekot Micro-Watershed, Tigray, Ethiopia. Journal of Geographic Information System, 7, 177-190.

[11] Hlaing, TK., Haruyama, SAye, MM, 2008. Using GIS-based distributed soil loss modeling and morphometric analysis to prioritize watershed for soil conservation in Bago river basin of lower Myanmar. Front Earth Sci China, 2,465-478.

[12] Horton RE, 1945. Erosion Development of Streams and Their Drainage Basins: Hydrophysical Approach to Quantitative Morphology. Bulletin of the Geological Society of America, 56, 275370

[13] Javed A, Khanday MY, Ahmaed R, 2009. Prioritization of Subwatersheds based on morphomeric and land-use analysis using remote sensing and GIS techniques. J Indian Soc Remote Sensing, $37,261-274$

[14] Javed A, Khanday MY and Rais S, 2011. Watershed prioritization using morphometric and land use/land cover parameters: a remote sensing and GIS based approach, Journal of the Geological Society of India, 78 (1), 2011, 63-75.

[15] Kumar A, Darmora A, Sharma A, 2012. Comparative assessment of hydrologic behavior of two mountainous watersheds using morphometric analysis. Hydrology Journal 35(3\&4),76-87.

[16] Lama TD, Singh RK., Saikia US \& Satapathy KK., 2015. Geomorphometric analysis of a hilly watershed in north east India: International Journal of Agricultural, Environment and Biotechnology, 8(1), 29-36

[17] Miller VC, (1953). A quantitative geomorphologic study of drainage basin characteristics in the Clinch Mountain area, Virginia and Tennessee, Project NR 389042, Tech Report 3. Columbia University Department of Geology, ONR Geography Branch,New York

[18] Nishant V, Jagdish CK. \& Rohit C, 2013. Morphometric Analysis Using GIS for Sustainable Development of Hydropower Projects in Lower Satluj River Catch in Himachal Pradesh, India. Int $J$ of Geomatics and Geosciences. 3(3), 469-471. 
[19] Obi Reddy GE, Maji AK., Gajbhiye KS, 2002. GIS for Morphometric Analysis of drainage basins, GIS India, 4, 9-14

[20] Pareta K. \& Pareta U, 2011. Quantitative Morphometric Analysis of a Watershed of Yamuna Basin, India using ASTER (DEM) Data and GIS, International Journal of Geomatics and Geosciences, 2(1), 248269.

[21] Schumm SA, 1956. Evolution of drainage systems and slopes in badlands at Perth Amboy, New Jersey. Geol Soc Am Bull 67:597646

[22] Selvan MT, Ahmad S, Rashid SM (2011) Analysis of the Geomorphometric parameters in high altitude Glacierised terrain using SRTM DEM data in Central Himalaya, India. ARPN J Sci Technol 1(1):22-27

[23] Sethupathi AS, Lakshmi Narasimhan C, Vasanthamohan V, Mohan SP, 2011. Prioritization of mini watersheds based on morphometric analysis using remote sensing and GIS in a drought prone Bargur Mathur sub watersheds, Ponnaiyar River basin, India. Int. J. Geomat Geosci, 2(2), 403-414

[24] Sharma T, Jaglan MS, Singh O \& Kumar S, 2012. Morphometric characterization of Tangri watershed in lower Siwalik and piedmont zone of Haryana and Punjab. Hydrology Journal, 35(3-4), 94-110.

[25] Singh PK, Singh UC, 2009. Water resource evaluation and management for Morar river basin, Gwalior district, Madhya Pradesh using GIS. E-J Earth Sci India 2,174-186

[26] Smith KG, 1950. Standards for grading texture of erosional topography. Am J Sci , 248,655-668

[27] Soni S, 2016. Assessment of morphometric characteristics of Chakrar watershed in Madhya Pradesh India using geospatial technique. Appl. Water Sci.

[28] Strahler AN, 1964. Quantitative geomorphology of basins and channel networks. In: Chow VT (ed.) Handbook of applied hydrology. McGraw Hill Book Company, New York, USA. 439-476.

[29] Strahler A.N, 1957. Quantitative analysis of watershed geomorphology, Transactions-American Geophysical Union, 38, 913920.

[30] Thomas J, Joseph S, Thrivikramaji KP, 2010. Morphometric aspects of a small tropical mountain river system, the southern Western Ghats, India. International Journal of Digital Earth 3(2),135-156

[31] Wandre SS and Rank HD, 2013. Assessment of morphometric characteristics of Shetrunji river basin using remote sensing and GIS Inter. J. of Agriculture, Environment and Biotechnology, 6(3), 503514.

[32] Yasmin, Polisgowdar, BS., Satish Kumar, U, Ayyangoudar MS, Narayan Rao K , 2013. Morphometric analysis of Milli watershed of Raichur district using GIS. Karnataka Journal of Agricultural Science, 26(1), 92-96. 